\title{
The effects from the United States and Japan to emerging stock markets in Asia and Vietnam
}

\author{
Nguyen Thi Ngan ${ }^{*}$, Nguyen Thi Diem Hien, Hoang Trung Nghia
}

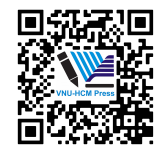

Use your smartphone to scan this QR code and download this article

University of Economics and Law, VNUHCM

\section{Correspondence}

Nguyen Thi Ngan, University of Economics and Law, VNUHCM

Email: ngannt@uel.edu.vn

History

- Received: 17/3/2017

- Accepted: 20/11/2019

- Published: 31/12/2019

DOI : 10.32508/stdjelm.v3i4.586

\section{Check for updates}

\section{Copyright}

(c) VNU-HCM Press. This is an openaccess article distributed under the terms of the Creative Commons Attribution 4.0 International license.

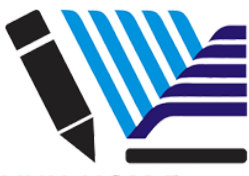

VNU-HCM Press

\begin{abstract}
The subprime mortgage crisis in the United States (U.S.) in mid-2008 suggests that stock prices volatility do spillover from one market to another after international stock markets downturn. The purpose of this paper is to examine the magnitude of return and volatility spillovers from developed markets (the U.S. and Japan) to eight emerging equity markets (India, China, Indonesia, Korea, Malaysia, the Philippines, Taiwan, Thailand) and Vietnam. Employing a mean and volatility spillover model that deals with the U.S. and Japan shocks and day effects as exogenous variables in $\operatorname{ARMA}(1,1), \mathrm{GARCH}(1,1)$ for Asian emerging markets, the study finds some interesting findings. Firstly, the day effect is present on six out of nine studied markets, except for the Indian, Taiwanese and Philippine. Secondly, the results of return spillover confirm significant spillover effects across the markets with different magnitudes. Specifically, the U.S. exerts a stronger influence on the Malaysian, Philippine and Vietnamese market compared with Japan. In contrast, Japan has a higher spillover effect on the Chinese, Indian, Korea, and Thailand than the U.S. For the Indonesian market, the return effect is equal. Finally, there is no evidence of a volatility effect of the U.S. and Japanese markets on the Asian emerging markets in this study.
\end{abstract}

Key words: Spillover, emerging markets, volatility effect, day effect

\section{INTRODUCTION}

In recent years, the world - especially developing countries - experienced a strong capital liberalization, financial market reform and advances in information technology. Consequently, information transmits across global financial markets more freely than ever, resulting in an increased linkage between stock markets. It has been found that the deeper the level of global financial integration, the more likely it is that financial markets of developing countries are affected by volatility spillover effects from mature financial markets. The latest financial turmoil began from U.S. in 2007 and spread to Asian markets in the early of 2008 through different mechanisms, such as increasing market volatility or market and funding illiquidity ${ }^{1}$. Following that crisis, Asian financial markets became highly volatile and shook violently. This means that there is an increase in the linkage between the Asian stock markets and the US market. Due to its size and economic importance in the world, the U.S. potential impact on emerging markets cannot be denied. Likewise, Japan as a major investor and trading partner of many Asian countries is expected to exert its influenced on these markets. Japan is the world's fourth largest stock exchange in terms of aggregate market capitalization of listed companies, and the largest in Asia. Japanese investors also hold a large amount of Asian assets ${ }^{2}$. Thus, the relationship between Japanese and Asian markets has become an important factor for investors and trade.

The volatility transmissions between stock markets have been the object of study of both practitioners and academia over the years. Understanding the level of correlations between stock markets would be a great help to investors and hedgers in their international portfolio diversification and optimization. A plenty of studies provided evidence for the spillover effects from the U.S. and Japan to other stock markets. This paper attempts to empirically examine the level of spillover effects from these two large mature markets on eight Asian emerging and Vietnamese stock markets. The $\operatorname{ARMA}(1,1)-\operatorname{GARCH}(1,1)$ is utilized. In particular, the return spillover are modelled using $\operatorname{ARMA}(1,1)$, volatility spillover is estimated using a two-step GARCH $(1,1)$ model. The data of this study is from 2000 to 2017, covering the period prior, during, and after the global financial crisis in 2007. This extensive coverage lends credibility to the results of this analysis. The empirical results in this research may be helpful for academics, domestic policy makers and professionals in understanding the magnitude of volatility spillover effects of the U.S. and Japanese stock markets on the Asian emerging stock markets. 
Moreover, this study contributes to the growing literature on the spillover effects and volatility transmission of equity returns.

The remainder of the paper is organized as follows. A literature review on the study of return and volatility spillover across markets is presented in the next section. Section Methodology gives details about the financial model for estimating volatility transmissions and spillover effects and as well as estimation procedure. Research data and the descriptive statistics are provided in Section Data. The empirical results are given in Section Empirical Results and finally, in the last chapter, the paper closes with concluding comments.

\section{LITERATURE REVIEW}

The study of market integration through analyzing both returns and volatility spillover has important implications for the modern portfolio theory. Several empirical literature provides strong evidence of market interdependence and integration among national stock markets.

Mervyn and Wadhwani ${ }^{3}$ applied correlation coefficients to stock market returns in order to examine how the market crash in the U.S. influenced the stock markets in Japan and the U.K. by using the GARCH model, co-integration tests, and the probability of specific events. The results show that the U.S. stock market crash significantly increased the correlation coefficients between multiple markets. Pan and Hsueh ${ }^{4}$ examined the nature of transmission of stock returns and volatility between the U.S. and Japanese stock markets employing a two-step GARCH approach. By using futures prices on the S\&P500 and Nikkei225 stock indexes, they found that there are unidirectional contemporaneous return and volatility spillovers from the U.S. to Japan. In particular, the U.S. influence on Japan in returns is approximately four times as large as the other way around. There are also no significant lagged spillover effects in both returns and volatility from the Japan to the U.S. while a significant lagged volatility spillover is observed from the U.S. to Japan.

Cha and $\mathrm{Oh}^{5}$ studied weekly stock indices of the U.S., Japan and four Asian NIEs from 1980 to 1998. They reported that the stock market crash the U.S. market began to have a significant impact on the Hong Kong and Singapore after the October 1987, yet its influence on Taiwan and South Korea remained unchanged. Employing a multivariate GARCH in Mean, Zaid ${ }^{6}$ investigated the international transmission of daily stock index volatility movements from the U.S. and U.K. to selected Middle Eastern and North African emerging markets, namely Egypt, Israel, and Turkey. The study finds that Egypt and Israel are significantly influenced by the U.S. stock market while Turkey is not.

Batareddy et al. ${ }^{7}$ investigated the stability of the long - run relationships between emerging (India, China, South Korea, and Taiwan) and developed stock markets (the U.S. and Japan) using use time varying cointegration tests with the sample data from mid 1998 to 2008. Their empirical findings support the presence of one long - run relationship (cointegration vector) between emerging and developed stock markets and the individual Asian emerging stock markets tend to display stronger linkages with the U.S. rather than with their neighbors.

Dhanaraj et al. ${ }^{8}$ using FEVD analysis in researching on the dynamic interdependence between the U.S. and Asian markets revealed the dominance of the U.S. stock market on Asian markets and that Asian stock markets are not immune to the shocks originating in the USA though the effects of shocks vary considerably across markets.

For the Vietnamese stock market, Farber et al. ${ }^{9}$ show that there exist anomalies stock returns through clusters of limit-hits and limit-hit sequences in HSC. Besides, there is a strong herd effect toward the extreme positive returns in market portfolios. Moreover, the specification of ARMA- GARCH can help capture issues such as serial correlations and fat-tails for a stabilized period, and policy decisions on the technicalities of trading can influence movements in risk level through the conditional variance behavior of HSC stock returns.

Using the correlation contagion test and Dungey et al.'s ${ }^{10}$ contagion test by EGARCH model, Wang and Lai ${ }^{11}$ find contagion effects between the Vietnamese and Japanese, Singaporean, Chinese, and the U.S. stock markets. They also show that the Japanese stock market causes stronger contagion risk in the Vietnamese stock market compared to China, Singapore, and the U.S. The stronger interdependence effects of Chinese and U.S. stock markets causes weaker contagion effects in the Vietnamese.

In summary, we have seen that most empirical studies have focused on the effects of developed markets both across the world and in the U.S., Japan to stock markets of other emerging countries. However, empirical examination of stock markets in Asia and Vietnam are limited, which necesitate further studies. Such markets are in the transitioning period with many economic reforms as well as the liberalization of capital markets. Similarly, Vietnam has continuing taken steps to reform its economy for the last 30 years. The 
nation has taken many significant transformations to become a market-oriented economy including the improvement of the banking and financial system and opening the market for foreign investors ${ }^{9}$.

\section{METHODOLOGY}

Fama ${ }^{12}$ and others have documented that stock returns exhibit mild serial correlations. In particular, large changes in daily stock prices tend to be followed by large changes and small price changes tend to be followed by small changes (see Mandelbrot ${ }^{13}$; and Fama ${ }^{12}$ ). The generalized autoregressive conditionally heteroscedastic (GARCH) family is designed to model the conditional mean and volatility of stock returns by taking into account the above properties. Since its introduction, the GARCH model has been generalized and extended in various directions.

Following Liu and Pan ${ }^{14}$, this paper allows innovations in the U.S. and Japan to influence the equity return of Asian emerging markets through the error term. The importance of modeling the volatility effect in financial markets during the financial turmoil has increased significantly and there has been a correspondingly large amount of literature over time to address the issue. Currently, the GARCH models are amongst the most popular econometric models used in academic studies.

Towards the volatility spillover, the GARCH $(1,1)$ model may be appropriate to capture the volatility gathering in the data (Brooks $\left.{ }^{15}\right)$. The $(1,1)$ in parentheses is a standard notation in which the first number refers to how many autoregressive lags, or ARCH terms, appear in the equation, while the second number refers to how many moving average lags are specified, which is often called the number of GARCH terms. The conditional variance is a linear function of 1 lag of the squares of the error terms $\left(\varepsilon_{t}\right)$ (also referred to as the "news" from the past) and 1 lag of the past values of the conditional variances $\left(\sigma_{t}\right)$ or the GARCH terms, and a constant $\omega$. Therefore, the model used in our research is the $\operatorname{ARMA}(1,1)$ $\operatorname{GARCH}(1,1)$ and can be summarized as below.

\section{Developed markets: the U.S. and Japan}

We begin by specifying an appropriate ARMAGARCH model, daily returns of the U.S. and Japan. We assume that the U.S. and Japan stock market returns are not affected by other markets and those returns are estimated through the following ARMA(1)$\operatorname{GARCH}(1,1)$ model with the mean and variance equations:

$$
\begin{array}{r}
r_{t, i}=\phi_{0, i}+\phi_{1} r_{t-1, i}+\phi_{2} \varepsilon_{t-1, i}+\sum_{j=1}^{4} d_{j} D_{j, t, i} \\
+\varepsilon_{t, i} \quad(1)
\end{array}
$$

$$
\begin{gathered}
\varepsilon_{t, i}=\sigma_{t, i} z_{t} \quad z_{t} \sim N(0,1) \\
\sigma_{t, i}^{2}=\alpha_{0, i}+\alpha_{1} \sigma_{t-1, i}^{2}+\alpha_{2} \varepsilon_{t-1, i}^{2}
\end{gathered}
$$

where $r_{t}$ is the daily stock index return; $i$ represents the U.S. and Japan; $D_{j t}$ is dummy variable for Monday, Tuesday, Wednesday and Thursday respectively; and $\varepsilon_{t}$ is the residual.

The residual $\varepsilon_{t}$ is the short-term fluctuation which expresses the unexpected events, new information or innovation in the U.S. and Japanese stock markets and spreads to eight Asian emerging markets and Vietnam. The larger the residuals are, the more likely they spread to Asian markets. Therefore, the residuals are employed to capture to the spillover effects from the U.S. and Japan to Asian markets.

\section{Emerging markets and Vietnam}

On the assumption that Asian markets could be affected by both the U.S. and Japanese markets, we consider the case where the international transmission from the U.S. and Japanese market could exist in terms of the mean and volatility effects. We construct a mean and volatility spillover model that deals with the shocks from the U.S. and japan as an exogenous variable in a ARMA-GARCH to the Asian markets by substituting the residual derived from equations (1) and its square from equations (2) of the U.S. and Japan market into the following ARMA-GARCH model.

Due to different trading time, a shock in the U.S. stock market during day $t$ will not be reflected in the Asian emerging stock markets until day for Hong Kong, Singapore, and Thailand.

That is, our model is given by:

For the Taiwanese market:

$$
\begin{gathered}
r_{t}=\phi_{0}+\phi_{1} r_{t-1}+\phi_{2} \varepsilon_{t-1}+\sum_{j=1}^{4} d_{j} D_{j, t}+\lambda_{U S} e_{U S, t-1} \\
+\lambda_{J P} e_{J P, t-1}+\varepsilon_{t}
\end{gathered}
$$


For others:

$$
\begin{array}{r}
r_{t, i}=\phi_{0}+\phi_{1} r_{t-1, i}+\phi_{2} \varepsilon_{t-1, i}+\sum_{j=1}^{4} d_{j} D_{j, t, i} \\
+\lambda_{U S} e_{U S, t-1}+\lambda_{J P} e_{J P, t}+\varepsilon_{t, i} \\
\varepsilon_{t, i}=\sigma_{t, i} z_{t} \quad z_{t} \sim N(0,1) \\
\sigma_{t, i}^{2}=\alpha_{0}+\alpha_{1} \varepsilon_{t-1, i}^{2}+\alpha_{2} \sigma_{t-1, i}^{2}+\gamma_{U S} e_{U S, t-1}^{2} \\
+\gamma_{J P} e_{J P, t}^{2}
\end{array}
$$

Where $e_{U S, t-1}$ and $e^{2} U S, t-1$ are the residual and the square of the residual for the U.S. market estimated in equation (1) and (2). The model allows us to model the volatility transmission spillovers between markets, with the data generating processes for the timevarying covariances across markets, rather than an unconditional consistent shock. We allow for mean spillover effects by including residual of S\&P500 and Nikkei225 retrieved from the equation (1) and include the residual squares obtained from Equation 2 for S\&P500 and Nikkei225 in variance equation, to capture the volatility spillover effects. The coefficient $\lambda_{U S}, \lambda_{J P}$ captures the mean spillover effect (cross-mean spillover) and the coefficient $\gamma_{U S}, \gamma_{J P}$ captures the volatility spillover effect (cross- volatility spillover) from the US and Japan. Statistically significant values for $\phi_{1}$ and $\alpha_{2}$ respectively, indicate the influence of own-mean and own-volatility spillovers from previous returns of Asian markets returns. Notice that the lag of the residuals of the U.S. and Japan is used due to different time zones between the US and Japan.

\section{DATA}

Fuelled by an increase of capital in recent years, the stock markets of the emerging markets in the Asian region have experienced a rapid growth. Data employed in the thesis are daily adjusted closing for 8 indexes of emerging markets in Asia, namely Taiwan, Korea, Indonesia, Philippines, China, Thailand, Malaysia, Indian (as classified by Morgan Stanley Capital International (MSCI) 2015). In addition, Vietnam's market is also considered. As a result, stock indices used are TSEC weighted index TWII (Taiwan), Kospi Index KS11 (Korea), Jakarta Composite Index JKSE (Indonesia), PSEi-Index PSEI.PS (Philippines), SET Index (Thailand), KLSE (Malaysia), S\&P BSE SENSEX Index (Indian), Shanghai Composite Index (China), and VN-Index (Vietnam). The data are retrieved from Yahoo Finance and Datastream. The sample period spans from January $2^{\text {nd }}, 2000$, to May $31^{\text {st }}$, 2017. Daily returns data is able to capture most of the possible interactions.

For the U.S. stock market, we used the Standard and Poor 500 (S\&P 500) Index, which is a market value weighted index and one of the common benchmarks for the U.S. stock market. The index includes 500 leading companies and captures approximately $80 \%$ coverage of available market capitalization. For the Japanese stock market, we employed the Nikkei225 Index, the leading and most-respected index of Japanese stocks. It is a price-weighted index comprised of Japan's top 225 blue-chip companies traded on the Tokyo Stock Exchange. the Nikkei is the most widely quoted average of Japanese equities, represents roughly $50 \%$ of the total market capitalization for the Tokyo Stock Exchange.

The number of observations is approximately 4300 for each country. The data for the whole period are illustrated in the Appendix A. The data of stock price exhibit large fluctuations during the whole p eriod. The paper analyzes the exogenous effects of the U.S. and Japanese returns and volatilities on Asian countries. The stock indices and their home countries are presented in Table 2. Also presented are their trading hours in both local and UT time for the purpose of studying the same effects. As can be seen from the table (Trading-UTC column), the U.S. market closes later than the other Asian stock markets; therefore, a shock in the U.S. stock market during day $t$ will not be reflected in the Asian emerging stock markets until day $t+1$. Thus, the appropriate pairing is time $t-1$ for the U.S. and time $t$ for the Asia markets. Furthermore, as Table 2 shows, the Japanese market is closed earlier than the other Asian stock markets, except Taiwan. Therefore, the appropriate pairing is time $t-1$ for Japan and time $t$ for Taiwan, and it is time $t$ for Japan and time $t$ for Hong Kong, Singapore, and Thailand.

The indices are transformed to a daily rate of return as below, which are defined as the natural logarithmic returns in two consecutive trading days:

$$
r_{t}=\ln \left(p_{t}\right)-\ln \left(p_{t-1}\right)=\ln \left(\frac{p_{t}}{p_{t-1}}\right)
$$

Where $r_{t}$ is the daily log return, $p_{t}$ and $p_{t-1}$ are the daily adjusted closing price of each stock indices at time $\mathrm{t}$ and $\mathrm{t}-1$.

The plots for the daily log returns fluctuate around a zero mean (see Figure 1). Each of all series appears to show the signs of ARCH effects in that the amplitude of the returns varies over time. 


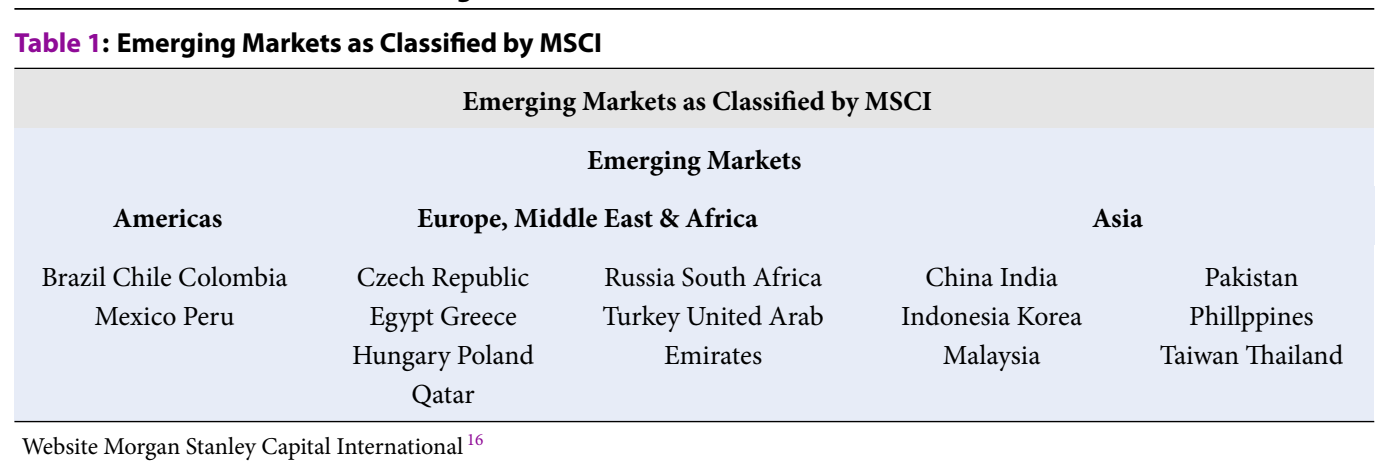

Table 2: Indices, home countries, time-zones and trading hours in local and GMT time

\begin{tabular}{|c|c|c|c|c|c|c|}
\hline \multirow[t]{2}{*}{ Index } & \multirow[t]{2}{*}{ Country } & \multirow[t]{2}{*}{ Time-zone } & \multicolumn{2}{|c|}{ Trading - local time } & \multicolumn{2}{|c|}{ Trading - UTC } \\
\hline & & & Open & Close & Open & Close \\
\hline S\&P 500 & The U.S. & UTC-5 & $9: 30$ & $16: 00$ & $14: 30$ & 21:00 \\
\hline Nikkei 225 & Japan & $\mathrm{UTC}+9$ & $9: 00$ & $15: 00$ & 0:00 & $6: 00$ \\
\hline TWII & Taiwan & $\mathrm{UTC}+8$ & 9:00 & $13: 30$ & 1:00 & $5: 30$ \\
\hline KS11 & Korea & $\mathrm{UTC}+9$ & 9:00 & $15: 30$ & 0:00 & $6: 30$ \\
\hline JKSE & Indonesia & $\mathrm{UTC}+8$ & $9: 30$ & $16: 00$ & $1: 30$ & 8:00 \\
\hline PSEi & Philippines & $\mathrm{UTC}+8$ & $9: 30$ & $15: 30$ & $1: 30$ & $7: 30$ \\
\hline SET & Thailand & $\mathrm{UTC}+7$ & $10: 00$ & $16: 30$ & 3:00 & $9: 30$ \\
\hline KLSE & Malaysia & $\mathrm{UTC}+8$ & 9:00 & $17: 00$ & $1: 00$ & 9:00 \\
\hline $\begin{array}{l}\text { S\&P BSE SEN- } \\
\text { SEX }\end{array}$ & Indian & $\mathrm{UTC}+05: 30$ & 9:15 & $15: 30$ & $3: 45$ & 10:00 \\
\hline Shanghai & China & $\mathrm{UTC}+8$ & $9: 30$ & $15: 00$ & $1: 30$ & $7: 00$ \\
\hline $\mathrm{VN}$ & Vietnam & $\mathrm{UTC}+7$ & 9:00 & $15: 00$ & 2:00 & 8:00 \\
\hline
\end{tabular}

Volatility clustering - the periods of high volatility alternate periods of low volatility - can be observed (large and small swings tend to cluster, see Figure 1. Abusing the terminology slightly, it could be started that "volatility is autocorrelated". Observing the time series data set of returns, we see that there exists heteroskedasticity in the model. However, we cannot determine whether this is enough to warrant consideration.

Descriptive characteristics for the daily stock index returns of emerging markets are given in Table 3.

It can be seen that the average daily returns are positive (except for TWII with negative mean returns) but negligibly small compared to the sample standard deviation. Six out of eight Asian markets (with the exception of China and Taiwan) have a higher return than the U.S. and Japan. This is why the mean is often set at zero when modeling daily portfolio returns ${ }^{17}$ which reduces the uncertainty and imprecision of the estimates. PSEI shows the most extreme values of daily market returns compared to the rest. China has the highest standard deviation whereas Malaysia has lowest.

The returns series display similar statistical properties as far as the third and fourth moments are concerned. More specifically, the returns series are skewed (either negatively or positively) and the large returns (either positive or negative) lead to a large degree of kurtosis. Excess kurtosis is a measure of peakedness or flatness of data in comparison to normal distribution. Both the indices show evidence of fat tails (leptokurtic) since the kurtosis exceeds 3 (the normal value), implying that the distribution of these returns has a much thicker tail than the normal distribution. As we know, skewness is a measure of symmetry, which is equal to zero for normal distribution. The skewnesses of all markets (except PSEI.PS) are also negative, indicating that the distribution has an asymmetric tail extending out to the left and is referred to as "skewed to the left". This leads the standard deviation of all mar- 
kets which presents the "risk" is underestimated when kurtosis is higher and skewness is negative.

The Ljung-Box (LB) Q statistics for daily stock returns of both assets are highly significant at five-percent level indicate the presence of serial correlations. Furthermore, the Ljung-Box Q statistics for squared returns are much higher than that of raw returns indicate the time-varying volatility. The p-value of ArchTest shown in the last row are all zero to both places, resoundingly rejecting the "no ARCH" hypothesis.

Furthermore, the presence of serial correlations and time-varying volatility make the traditional OLS regression inefficient. These features of the data lead us to consider the GARCH type models that can accommodate time-varying and persistent behavior of volatility of returns. We start modeling with $\operatorname{ARMA}(1,1)-\operatorname{GARCH}(1,1)$.

\section{EMPIRICAL RESULTS}

Empirical models for these Asian markets are as below:

$$
\begin{array}{r}
r_{t}=\phi_{0}+\phi_{1} r_{t-1}+\phi_{2} \varepsilon_{t-1}+\sum_{j=1}^{4} d_{j} D_{j, t}+\lambda_{U S} e_{U S, t-1} \\
+\lambda_{J P} e_{J P, t}+\varepsilon_{t}
\end{array}
$$

$$
\begin{gathered}
\varepsilon_{t, i}=\sigma_{t, i} z_{t} \quad z_{t} \sim N(0,1) \\
\sigma_{t}^{2}=\alpha_{0}+\alpha_{1} \varepsilon_{t-1}^{2}+\alpha_{2} \sigma_{t-1}^{2}+\gamma_{U S} e_{U S, t-1}^{2}+\gamma_{J P} e_{J P, t}^{2}
\end{gathered}
$$

The dummy variable for day effect is insignificant in most countries in mean equation, indicating there is no weekday effect in mean returns. It is worth noting that markets where day effect is present, the dummy variable has a negative sign and most falls on Monday. This result implies there is a difference between stock returns on Monday and Friday on these markets which is consistent with prior studies. Accordingly, the average stock return on Monday is negative and lower than the other weekdays. The Monday effect is a form of inefficient market when the Monday average return is affected by return of the other weekdays, especially the last Friday. Reactions of investors on Monday are normally unfavorable, resulting in a negative average return. This effect is related to financial behavior of investors.

Coefficients $\varphi_{1}$ in the U.S., Japan, Malaysia, Korea, Taiwain and Vietnam are positive and significant, suggesting that stock returns on Asian markets today are affected by stock returns of the previous day. The negative and significant coefficient $\varphi_{1}$ for Indian, Indonesian, Philippine and Thai markets indicates that there is no impact of return on the previous day on the today return.
The statistically significant values of $\lambda_{U S}, \lambda_{J P}$ suggest that returns on the U.S. and Japanese affect the conditional mean of the considered Asian markets returns (e.g. cross-mean spillover). The results for the conditional mean equations show statistically significant positive mean spillover effect from the U.S. and Japan returns, indicating that a high return in the two those mature markets are followed by high returns in the Asian markets. Global financial markets display a higher degree of correlation owing to globalization and more efficient dissemination of information. Stocks are more likely to be affected by developments in overseas markets.

Another noticeable finding is Japan has a stronger influence on Korea than the U.S. (0.370 versus 0.210$)$ while the U.S. has a stronger influence on Taiwan than Japan ( 0.436 versus 0.009$)$. These effects are likely due to the strong economic relationship between Japan Korea and the U.S. - Taiwan. However, these effects cannot be so easily explained and require further study for explanation. Vietnam's stock market exhibits the lowest influence from the U.S. compared with other examined markets. This is perhaps due to the tight capital control by the Vietnamese Government.

On the other hand, in terms of the volatility spillover, the estimates of GARCH parameters $\alpha_{1}, \alpha_{2}$ for Asian markets are significant and the sum of these two coefficients which measures the persistence of volatility is close to unity. The parameter estimates for the conditional variance $\alpha_{1}, \alpha_{2}$ are highly significant, indicating that the conditional variance process of the Asian markets returns is indeed time-varying. The ownvolatility spillover effect from the previous volatility $\alpha_{2}$ is highly significant whereas the cross-volatility spillover effect from the U.S. and Japan is insignificant. The statistically insignificant values for $\gamma_{U S}, \gamma_{J p}$ indicate there is no influence of volatility spillovers from the U.S. and Japan to the Asian markets. Possible reason is that their volatility is mainly explained by the Asian own volatility.

This diagnostics show that the residuals of the models are reasonably well-behaved. The portmanteau LB statistics in Panel B of Table 4 evaluate the serial correlations in the raw and squared standardized residuals of the model up to lags 7 and 9 and find that most of the conditional dependence in the return has been modeled reasonably well.

\section{DISCUSSION AND CONCLUSIONS}

This paper focuses on investigating the transmission volatility and spillover effects from the U.S. and Japan 


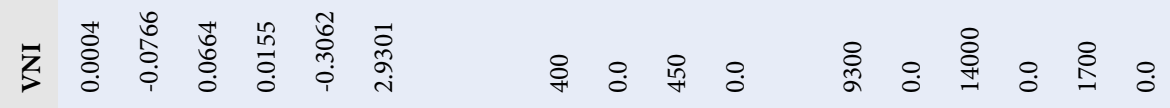

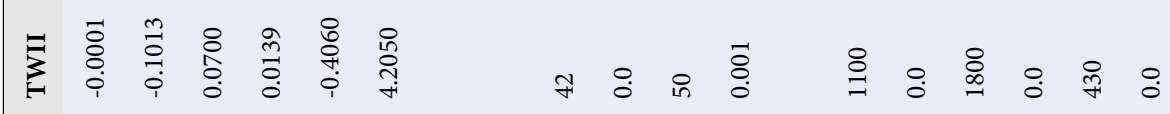

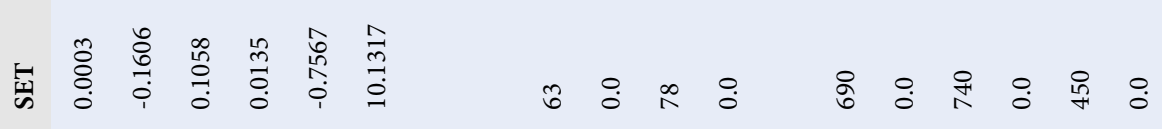

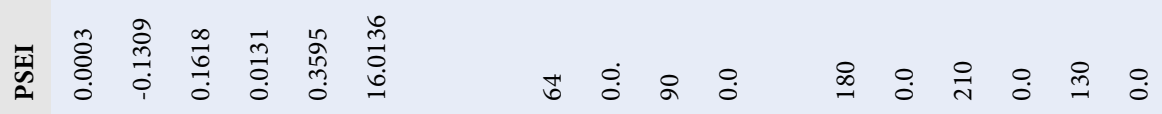

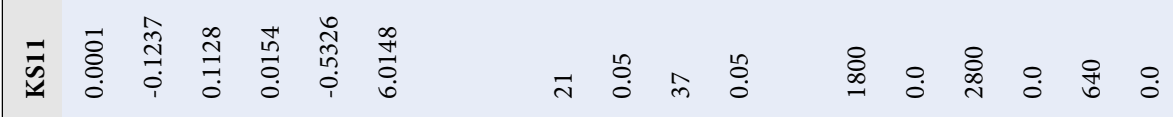

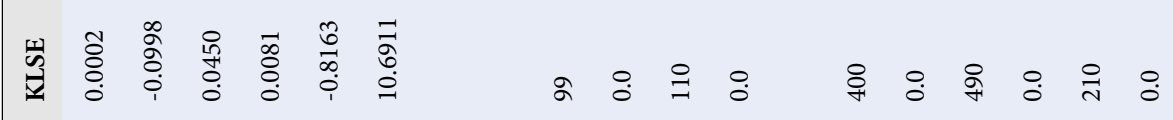

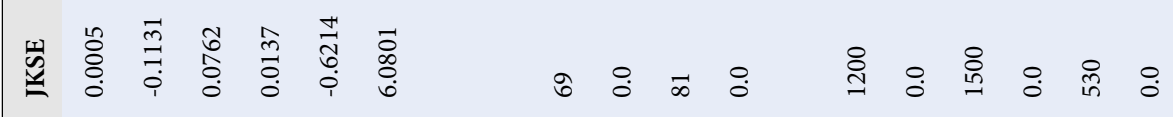

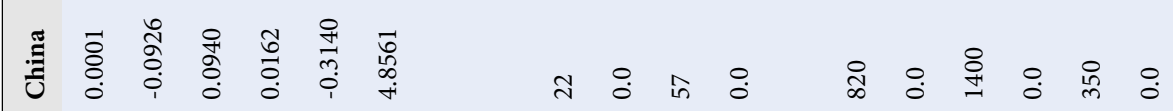

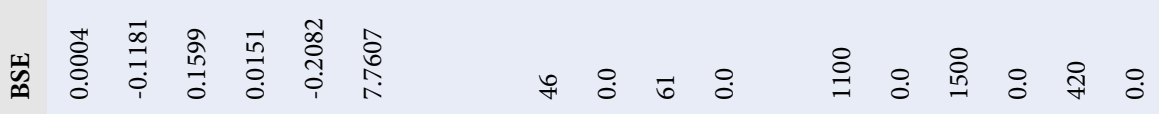

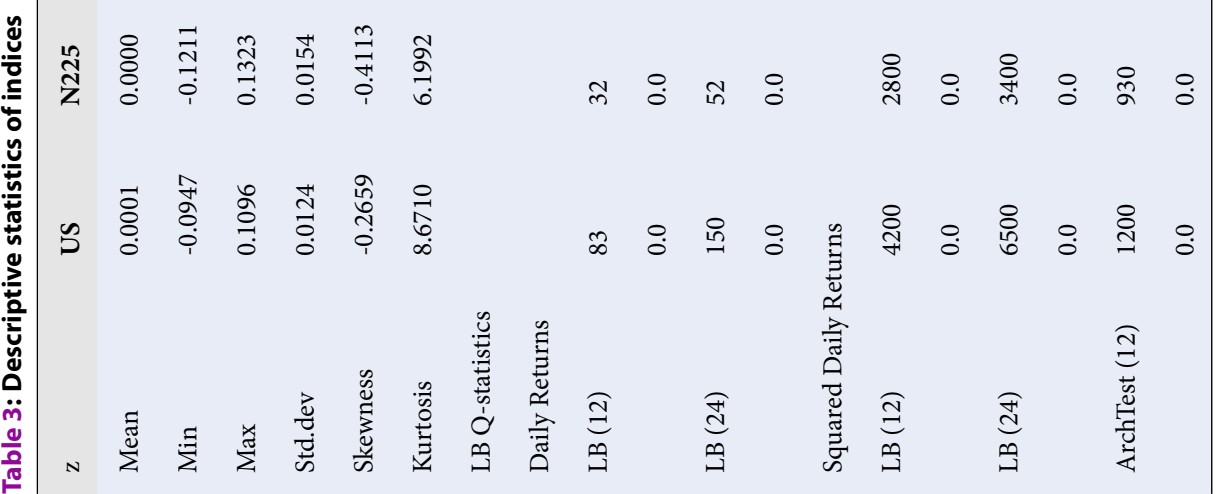




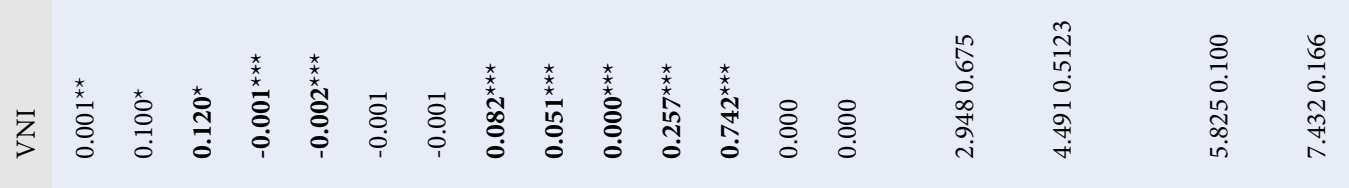

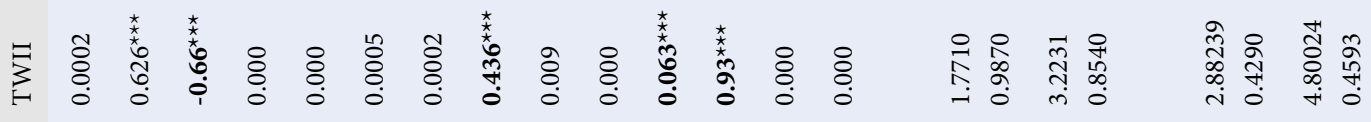

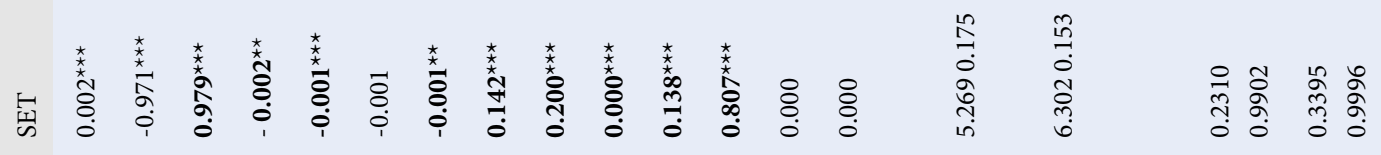

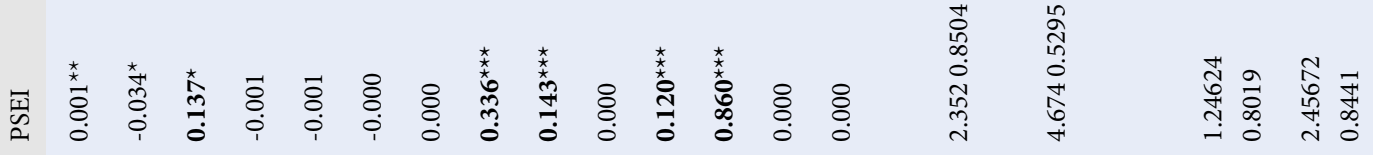

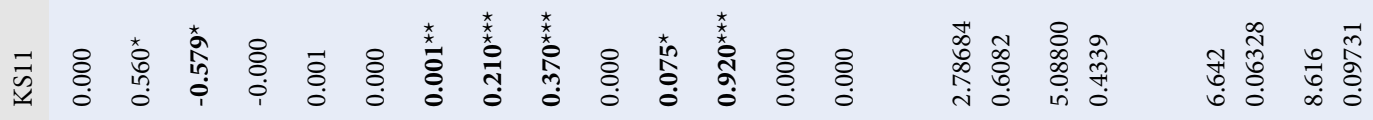

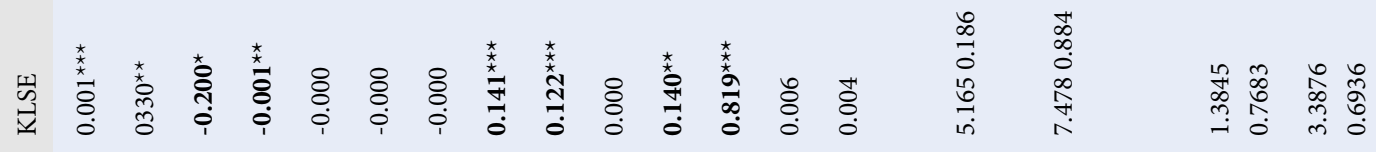

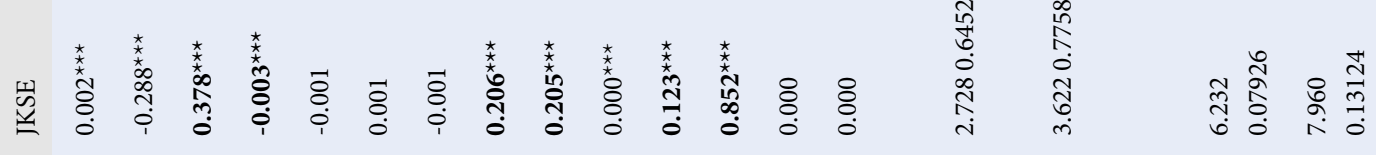

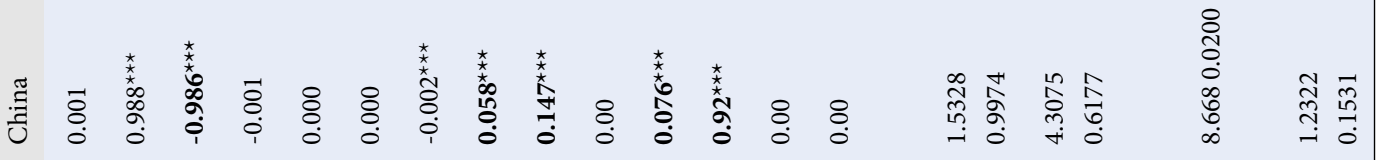

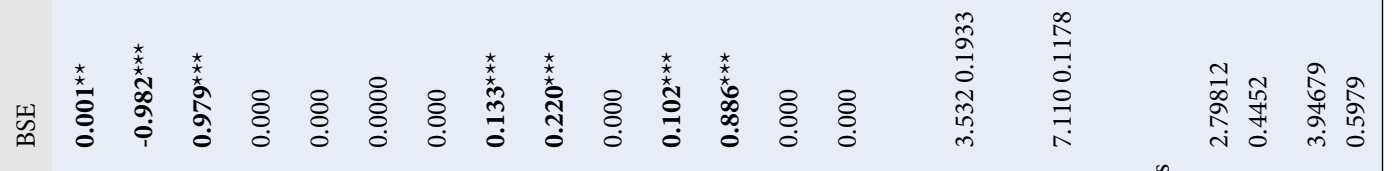

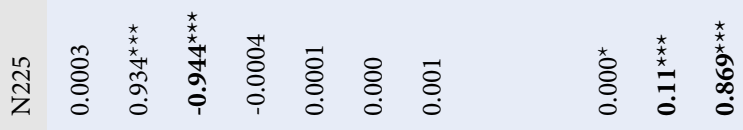

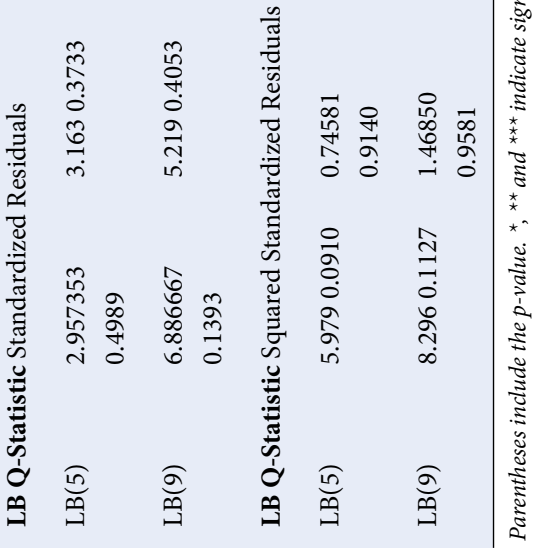




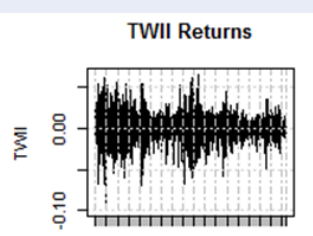

Jan 052000 Jan 042010

PSEI.PS Returns

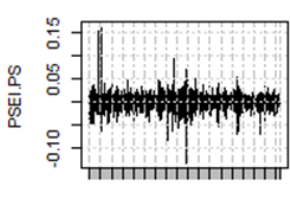

Jan 042000 Jan 042010

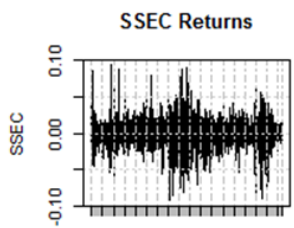

Jan 052000 Jan 042010

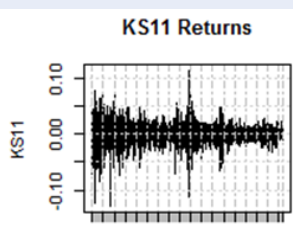

Jan 052000 Jan 042010

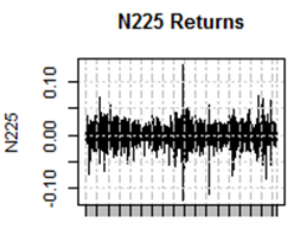

Jan 052000 Jan 042010

BSESN Returns

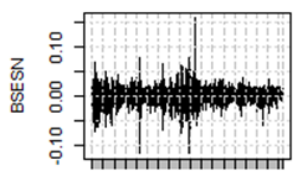

Jan 042000 Jan 042010

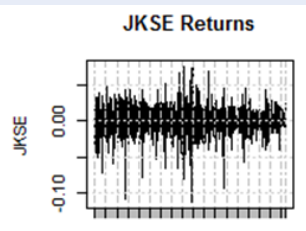

Jan 052000 Jan 042010

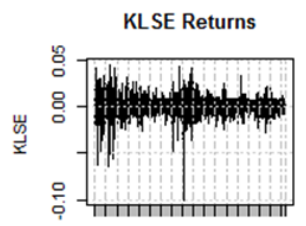

Jan 042000 Jan 042010
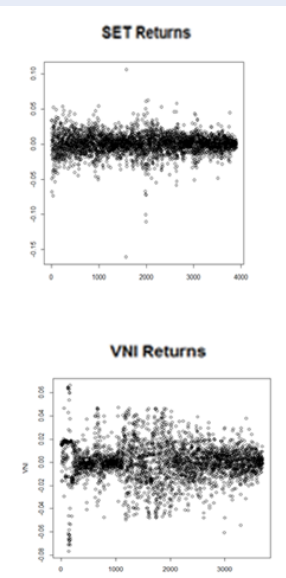

Figure 1: The daily returns of stock indices.

to eight Asian and Vietnamese stock markets by exploring the level of conditional correlations between markets from January $1^{s t}, 2000$ to May $31^{s t}, 2017$ using ARMA(1,1)-GARCH $(1,1)$ models. The results provided interesting findings which contribute to the understanding of the time-varying nature of mean and volatility spillover effects between developed and Asian emerging stock markets. We allow for mean spillover effects by including residual of S\&P500 and Nikkei225 obtained from the equation (1) and including the residual squares obtained from equation (2) for S\&P500 and Nikkei225 in variance equation to capture the volatility transmission effects. The results do not support the evidence of the day effect on all markets. For markets where the day effect, dummy variable has a negative sign and most fall on Monday. We also found clear evidence that the returns of the U.S. and Japan exert a positive influence on the returns on Asian markets. In addition, the cross-volatility spillover effect from the U.S. and Japan returns is insignificant whereas the ownvolatility spillover effect from Asian returns itself are highly significant.

These results are important for economic policymakers in order to safeguard the financial sector from international financial shocks. The investors can use this information for constructing efficient portfolios to reduce risks and enhance returns.

The majority of recent studies of international prices and volatility focus on the developed markets. Thus, the present paper also contributes to the literature by broadening the focus of the existing evidence. Further research is necessary for investigating the mean and volatility transmission through multivariate GARCH (M-GARCH) models. The ability of capturing crossmarket spillovers increases with MARCH specification because of its advantages.

\section{ABBREVIATIONS}

ARCH: Autoregressive Conditionally Heteroscedastic

ARMA: Autoregressive-Moving-Average

GARCH: Generalized Autoregressive Conditionally Heteroscedastic

LB: Ljung-Box

MSCI: Morgan Stanley Capital International

OLS: Ordinary Least Squares

The U.S.: The United States

\section{COMPETING INTERESTS}

The authors declare that they have no conflicts of interest. 


\section{AUTHORS' CONTRIBUTIONS}

This research is conducted by Nguyen Thi Ngan, Nguyen Thi Diem Hien and Hoang Trung Nghia, in which Nguyen Thi Ngan is mainly responsible for this research. Nguyen Thi Ngan is responsible for conceiving and designing the analysis, contributing data and analysis tools, performing the analysis and writing the paper. Nguyen Thi Diem Hien and Hoang Trung Nghia are responsible for collecting data; interpreting data and writing the paper.

\section{ACKNOWLEDGMENTS}

This result is funded by Vietnam National University Ho Chi Minh City (VNU-HCM) under grant number C2019-34-09.

\section{REFERENCES}

1. Frank N, Hesse H, Gonzlez-Hermosillo B. Transmission of Liquidity Shocks: Evidence from the 2007 Subprime Crisis; 2008.

2. Fornari, Fabio and Aviram Levy. Global liquidity in the 1990s: geographical allocation and long-run determinants, mimeo, Bank of Italy. 2000.

3. King AM, Wadhwani S. Transmission of Volatility between Stock Markets. Review of Financial Studies. 1990;3(1):5-33.

4. PanL MS, Hsueh P. Transmission of Stock Returns and Volatility between the U.S. and Japan: Evidence from the Stock Index Futures Markets. Asia-Pacific Financial Markets. 1998;5(3):211-225.
5. Cha B, Oh S. The relationship between developed equity markets and the pacific basins emerging equity markets. International Review of Economics Finance. 2000;9:299-322.

6. Abou-Zaid SA. Volatility Spillover Effects in Emerging MENA Stock Markets. International Review of Applied Economics. 2011;7(1-2):107-127.

7. Batareddy M, Gopalaswamy KA, Huang C. The stability of long-run relationships: a study on Asian emerging and developed stock markets (Japan and US). International Journal of Emerging Markets. 2012;7(1):31-48.

8. Dhanaraj S, Gopalaswamy AK, Babu MS. Dynamic interdependence between US and Asian markets: an empirical study. Journal of Financial Economic Policy. 2013;5(2):220-237.

9. Farber, André, Nguyen VN, Vuong QH. Policy Impacts on Vietnam Stock Market: A Case of Anomalies and Disequilibria 2000-2006. Centre Emile Bernheim Working Paper 2006. 2006;p. 005. 06/005.

10. Dungey M, Fry R, Gonzlez-Hermosillo B, Martin VL. Empirical Modelling of Contagion: A Review of Methodologies. Quantitative Finance. 2005;5(1):9-24.

11. Wang KM, Lai HC. Which Global Stock Indices Trigger Stronger Contagion Risk in the Vietnamese Stock Market? Evidence Using a Bivariate Analysis. Panoeconomicus. 2013;4:473-497.

12. Fama EF. The Behavior of Stock-Market Prices. The Journal of Business. 1965;38(1):34-105.

13. Mandelbrot BB. The Variation of Certain Speculative Prices. Journal of Business. 1963;36:394-419.

14. Liu YA, Pan MS. Mean and volatility spillover effets in the US and Pacific-Basin stock markets. Multinational Finance Journal. 1997;1:47-62.

15. Brooks C. Introductory econometrics for finance. 2008;Cambridge University Press, UK.

16. Website Morgan Stanley Capital International; 2017. https:// www.msci.com/emerging-markets.

17. Figlewski S. Forecasting Volatility Using Historical Data. 1994;NYU Working Paper No. FIN-94-032. 


\title{
Tác động từ thị trường chứng khoán Mỹ và Nhật Bản đến TTCK các nước mới nổi khu vực châu Ấ và Việt Nam
}

\author{
Nguyễn Thị Ngân* ${ }^{*}$ Nguyễn Thị Diễm Hiền, Hoàng Trung Nghĩa
}

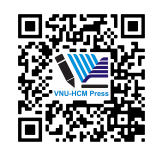

Use your smartphone to scan this QR code and download this article

\section{TÓM TẮT}

Cuộc khủng hoảng 2007-2008 nổ ra ở Hoa Kỳ kéo theo sự lao dốc của các thị trường chứng khoán các nước cho thấy tồn tại tác động lan truyên từ thị trường này sang thị trường khác. Mục tiêu của bài nghiên cứu nhằm kiểm tra mức độ lan truyền trong tỷ suất lợi nhuận và độ biến động tỷ suất lợi nhuận từ các thị trường chứng khoán phát triển (Hoa Kỳ và Nhật Bản) đến tám thị trường các nước mới nổi (Ấn Độ, Trung Quốc, Indonesia, Hàn Quốc, Malaysia, Philippines, Đài Loan, Thái Lan) và Việt Nam. Nghiên cứu sử dụng các biến ngoại sinh là cú sốc từ thị trường Mỹ và Nhật Bản và hiệu ứng ngày trong mô hình $\operatorname{ARMA}(1,1)-G A R C H(1,1)$ trên dữ liệu của các nước mới nổi khu vực châu Á và Việt Nam nhằm đánh giá tác động lan truyền. Nghiên cứu đưa ra một số kết quả như sau. Thứ nhất, hiệu ứng ngày tôn tại trên sáu trong số chín thị trường chứng khoán được nghiên cứu, ngoại trừ Ấn Độ, Đài Loan và Philippines. Thứ hai, tồn tại tác động lan truyền trong tỷ suất lợi nhuận giữa các thị trường với mức độ khác nhau, trong đó, Hoa Kỳ có tác động mạnh hơn đến thị trường Malaysia, Philippines và Việt Nam; ngược lại, Nhật Bản có hiệu ứng lan truyền cao hơn đến thị trường Trung Quốc, Ấn Độ, Hàn Quốc và Thái Lan; đối với thị trường Indonesia, hiệu ứng lan truyền từ Hoa Kỳ và Nhật Bản là tương đương. Cuối cùng, nghiên cứu không tìm thấy bằng chứng về hiệu ứng lan truyền trong độ biến động từ thị trường Hoa Kỳ và Nhật Bản đến các thị trường mới nổi khu vức châu Á và Việt Nam...

Từ khoá: Tác động lan truyền, thị trường mới nổi, tác động lan truyền độ, biến động, hiệu ứng ngày
Trương ĐH Kinh tế - Luật, ĐHQG HCM

Liên hệ

Nguyễn Thị Ngân, Trường ĐH Kinh tế - Luật, ĐHQG HCM

Email: ngannt@uel.edu.vn

Lịch sử

- Ngày nhận: 17/3/2017

- Ngày chấp nhận: 20/11/2019

- Ngày đăng: 31/12/2019

DOI : 10.32508/stdjelm.v3i4.586

\section{Check for updates}

\section{Bản quyền}

๑ Đ ĐHQG Tp.HCM. Đây là bài báo công bố mở được phát hành theo các điều khoản của the Creative Commons Attribution 4.0 International license.

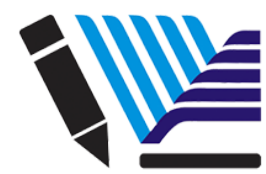

VNU-HCM Press
Trích dẫn bài báo này: Ngân $\mathrm{N} T$, Hiền $\mathrm{N} T \mathrm{D}, \mathrm{Nghĩa} \mathrm{H}$ T. Tác động từ thị trường chứng khoán Mỹ và Nhật Bản đến TTCK các nước mới nổi khu vực châu Á và Việt Nam. Sci. Tech. Dev. J. - Eco. Law Manag.; 3(4):440-450. 